\title{
Intrapersonal correlates of aggression in adolescents: determinants of undertaking the role of the perpetrator and the victim
}

\author{
Marzanna Farnicka ${ }^{A, B, C, D, E, F}$, Iwona Grzegorzewska ${ }^{A, B, C, D, E, F}$ \\ Department of Psychology, Faculty of Education, Sociology and Health Sciences, University of Zielona Gora, Poland
}

\section{BACKGROUND}

Youthful aggression, perceived both as a social phenomenon and a psychological issue, is the subject matter of numerous theoretical analyses and scientific studies. Usually, their aim is to determine the consequences of aggressive behaviour, especially the development of criminal behaviour. However, empirical studies devoted to the relations between aggressive behaviour of Polish youth and intrapersonal factors are still lacking. The main aim of the research presented in this paper was to determine the relationship between attachment, temperament, aggressiveness and aggressive behaviour among young people. For research purposes, the multidimensional aggression model developed by Anderson and Bushman was used.

\section{PARTICIPANTS AND PROCEDURE}

Measurements were carried out with the Buss-Perry Aggressiveness Scale, the Parent and Peer Attachment Inventory by Armsden and Greenberg, the Buss and Plomin Temperament Scale and the Mini DIA Questionnaire (Osterman and Björqvist). The studied group consisted of 120 young persons aged between 16 and 19 .

\section{RESULTS}

The research results support the conclusion that the dominant temperamental component of persons characterized by a high level of aggressiveness is anger. Also, correlations were found indicating that a high level of trust and a high level of alienation in the relationship with the mother are connected with anger as an aggressiveness component.

\section{CONCLUSIONS}

The actually undertaken aggressive behaviour depends on the prevailing aggressiveness dimension: the frequency of perpetrator-type behaviour increases along with the general aggressiveness level and the frequency of its manifestation in the form of physical and verbal aggression, while the frequency of victim-type behaviour increases along with the experienced level of anger and hostility.

\section{KEY WORDS}

aggression; hostility; temperamental characteristics; attachment styles

Corresponding Author - Marzanna Farnicka, Ph.D., Department of Psychology, Faculty of Education, Sociology and Health Sciences, University of Zielona Gora, 2 Energetyków Avenue, 65-001 Zielona Góra, Poland, e-mail:m.farnicka@wpsnz.uz.zgora.pl

authors' CONTRibution - A: Study design - B: Data collection - C: Statistical analysis - D: Data interpretation .

E: Manuscript preparation · F: Literature search · G: Funds collection

TO CITE THIS ARTICLE - Farnicka, M. A., \& Grzegorzewska, I. (2015). Intrapersonal correlates of aggression in adolescents: determinants of adopting the role of the perpetrator and the victim. Current Issues in Personality Psychology, 3(1), 25-35.

RECEIVED 24.11.2014 · REVIEWED 01.02.2015 · ACCEPTED 02.03.2015 · PUBLISHED 23.03.2015 


\section{BACKGROUND}

Children and adolescents increasingly often display hyperactivity and difficulties with impulse control, which may result in violence. In the literature it is pointed out that those processes may be connected with aggressiveness (Krahé, 2005). Aggressiveness is characterized as a personality trait that is conducive to uncontrolled aggressive behaviour and a tendency to externalize problems. The aggression of young people not only poses a challenge to their parents, teachers and peers but also influences the individual's development in a destructive way. Additionally, it is quite stable in time and persists in behaviour from childhood to youth (Farrington, 1991). It has also been established that child aggressiveness is a predictor for such problems as poor school performance (DeRosier, Kupersmidth, \& Paterson, 1994), problems with behaviour during lessons (Wentzel \& Ascher, 1995) or engaging in risky and criminal behaviour (Kupersmidth \& Coie, 1990). What is particularly important, aggressiveness in childhood is conducive to the development of many problems in adolescence and early adulthood, such as: disruption of education, abuse of psychoactive substances, problems with mental health, problems with holding down a job, spousal violence or delinquency (Fergusson, Horwood, \& Ridder, 2005; Moffitt, Caspi, Harrington, \& Milne, 2002). Aggression is also the most frequent cause of admission of children and adolescents to psychiatric clinics (Kazdin, 1995).

Aggression is of great interest to mental health professionals because it is predictive of criminality, substance misuse and personality disorders in adulthood, and can cause disruptions in the family, school, and peer relations (Coie, Dodge, \& Coppotelli, 1982; Elliott, 1994). Aggression is suggested to be a predictive factor for psychopathology, especially for externalizing problems, but the causal relationship between aggression and psychopathology is complex. Early aggressive acts are a risk factor for onset of externalizing symptoms, and aggression is suggested to be a long-term individual characteristic which is probably in association with personality traits pre-existing before the psychopathology.

The analysis of the determinants for aggressive behaviour confirms that many of them are connected with the development and persistence of aggressive behaviour in children and adolescents. Most often it is found that the factors facilitating aggressive behaviour are heterogeneous (Barnow, Lucht, \& Freyberger, 2005). They include biological characteristics (Cloninger, 1994) and shared or unshared environmental conditions affecting the individual (Garnefski \& Diekstra, 1996). As the previously conducted research reveals, an important role in shaping aggression in young people is played by personality factors. Relevant literature indicates that two of them, tem- perament and attachment, may constitute the significant primary elements conducive to the development of aggressive tendencies. Although most studies focus on the analysis of aggressive behaviour, one can suppose that aggressiveness as a personality trait constitutes a factor in susceptibility to problem externalization, including behaviour-related disorders and a tendency to use violence (Krahé, 2005; Olewus, 1979; Kaźmierczak, Błażek, \& Pastwa-Wojciechowska, 2013).

Many models of aggressive behaviour indicate that temperament and other personality variables influencing self-regulation and emotional reactivity are significant aggression risk factors (e.g. Anderson \& Bushman, 2002; Berkowitz, 2012; Dodge \& Pettit, 2003; Österman \& Björkqvist, 1998). Temperament may be characterized as observable manifestations of human dispositive and biological characteristics relatively stable over time (Rubin, Burkowski, \& Parker, 1998). Persons diagnosed with a so-called difficult temperament are more prone to emotional dysregulation, higher levels of negative affect and a behavioural response to even a slight change in stimulation. A tendency to frustration is an aspect of emotional reactiveness and, as an element of negative affect (anger as a temperamental component), influences impulse control and aggressive response in a situation of provocation (Eisenberg, Spinrad, \& Eggum, 2010; Rothbart, 2011). Cloninger (1997) stressed that other temperamental personality factors, such as sensation seeking, may predestine one to criminal behaviour and parent and peer rejection as well as other behavioural problems (e.g. alcohol abuse).

The adopted research model stresses that another important variable that may significantly influence the shaping of aggressive behaviour, and consequently aggression in adolescents, is attachment. Many studies indicate that the behaviour of caregivers in the first months of a child's life forms the foundations for the child's social abilities in the context of development of aggressive behaviour (Paterson, Reid, \& Dishion, 1992). In this sense, dispositive and intrapersonal characteristics of a child trigger an appropriate reaction of his or her primary caregiver, and the mutual interaction becomes the foundation for the development and shaping of emotional and social competencies of an individual. There are many reasons for which hostile, rejecting or cold parenthood leads to the development of the child's personality towards aggressiveness. Children may learn aggressive behaviour and a dysregulative response to stress from their caregivers (Paterson et al., 1992). They may also establish "inner operative models" as patterns of their roles in social interactions. Insecure attachment patterns shaped in a direct relation with a close caregiver lead to perception of others as hostile and untrustworthy (Bowlby, 1988), i.e. devel- 
opment of views that are linked with child aggressiveness (Dodge, 1986). And although most studies concerning links between attachment and aggression in children are conducted in early and middle childhood, one should not disregard the fact that attachment plays an import role in shaping the behaviour of adolescents as well. Studies on childhood revealed increased aggressiveness of children with an insecure attachment pattern (Renken, Egeland, Marvinney, Mangelsdorf, \& Sroufe, 1989; Fagot \& Kavanagh, 1990; Lewis, Feiring, McGuffog, \& Jaskir, 1984). In subsequent studies, analyses of the relationship between non-observance of norms and aggressiveness in childhood and antisocial behaviour in adolescence were undertaken, although only some of them explored their connections with attachment.

Finally, there are several concepts and empirical proofs indicating that biological sex is a significant factor increasing the tendency to personality-based aggression. There are studies confirming that men face a greater risk of problem externalization than women (Sanson, Oberkleid, Pedlow, \& Prior, 1991; Zahn-Waxler, 1993). The relation between sex and aggressiveness is used as an argument for the biological basis of antisocial behaviour (Archer \& McDaniel, 1995; Morton \& Rafto, 2004). However, there is an increasing amount of evidence demonstrating that the links between biological sex and aggression are not so direct as previously thought (Eagly \& Wood, 1999). Biological factors may be conducive to greater male susceptibility to aggressiveness if there are additional risk factors present, either in the situation itself or in specific environmental and personal determinants (cf. Björkqvist, Österman, \& Lagerspetz, 1994; Zocollilo, 1993). Researchers most often point to cultural factors, as families tend to accept aggression in boys more than in girls. Additionally, in the process of education, boys experience more control (Lytton \& Romney, 1991) and less warmth (Malatesta \& Wilson, 1988), which may constitute a significant risk factor for the development of aggressive behaviour (Rubin, Chen, McDougall, Bowker, \& McKinnon, 1995). In the research presented in this paper we evaluated the dependency between sex and personality-based aggression in young people as a predictor of aggressive behaviour.

\section{PARTICIPANTS AND PROCEDURE}

\section{RESEARCH MODEL AND RESEARCH METHOD}

The adopted research model makes use of the multidimensional aggression model based on the General Aggression Model (GAM) proposed by Anderson and Bushman (2002). It is a three-phase dynamic model in which an important role is played by situational factors, individual resources, current psycho-physical condition and numerous forms of feedback connected with the process of evaluation of the consequences of undertaken behaviour, which in turn influence the fixation or inhibition of certain behaviour patterns and interpretations in the future (Anderson \& Carnagey, 2004; Wojciszke, 2011). According to the GAM (Anderson \& Bushman, 2002), aggression is largely based on the activation and application of aggression-related knowledge structures stored in past experiences and memory, recognition of a given situation as hostile, threatening or provocative, and readiness for aggressive behaviour, which is connected with physiological arousal, cognitive processes and aggression-related anger. Thus activated, readiness for aggression is subject to decision-making processes as a result of which an individual reacts in an impulsive or reasoned manner. The question that arose in the context of the presented research relates to the possibility of treating aggressiveness (as a personality trait) as a factor of susceptibility to externalization problems in adolescence. Also, personality-based aggressiveness correlates in young people were sought.

\section{RESEARCH OBJECTIVE}

The present study has verified the assumptions concerning the impact of an individual's subjective features on adolescents' aggressiveness. Evaluation was also performed of such personality traits as temperament, attachment and aggressiveness level, and also aggressive types of behaviour, i.e. assuming the victim or perpetrator role. The assumption made for this research was that independent variables were antecedent to aggressiveness in ontogenesis and may therefore have an impact on its development and intensity. It is possible that in the course of personality development those variables become mutually interdependent. The analyses also took into account the age and sex of respondents and their socio-demographic data. The hypotheses formulated prior to the commencement of research were as follows: 1. The dominant temperamental feature in persons with a high level of aggressiveness is anger. 2. Insecure attachment (low level of attachment bond and trust and high level of alienation) positively correlates with high level of aggressiveness in all its dimensions. 3. There exists a relationship between age, sex and socio-demographic characteristics of respondents and their aggressiveness level. 4. High level of aggressiveness is a predictor for aggressive behaviour of an individual.

\section{RESEARCH MEASURES}

Attachment was evaluated with the two subscales of the Inventory of Parent and Peer Attachment (IPPA) 
developed by Armsden and Greenberg (1987) - experimental version, serving the purpose of evaluation by young people of affective-cognitive patterns of attachment as the source of psychological security. The theoretical framework for IPPA is the attachment theory originally formulated by Bowlby and recently elaborated upon by other researchers. Four broad dimensions of attachment are evaluated: attachment bond, level of mutual trust, quality of communication, and extent of anger and alienation. Each scale contains 25 questions coded on a 5-point Likert scale. The obtained scores fell within the range of 25 to 100 points, and for the particular subscales they were as follows: Attachment Bond and Trust 10-50, Communication 9-45, and Alienation 6-30. Cronbach's $\alpha$ reliability coefficients are as follows: Attachment Bond-Mother subscale .87, Attachment Bond-Father subscale .89 . The psychometric validity tests produced satisfactory results, but in Poland we are still using the experimental version, as the Polish parametrization of that method is still in progress. The test is widely used in the USA (e.g. Armsden \& Greenberg, 1987) and only sporadically used for research in Poland (Mazur \& Małkowska-Szkutnik, 2011; Gajewski \& Małkowska-Szkutnik, 2012; Grzegorzewska, 2013).

Information about temperament was gathered with the EAS Temperament Survey by A. H. Buss and R. Plomin in the Polish adaptation of W. Oniszczenko (1997). The version used was the self-descriptive version of the EAS-D questionnaire for adults designed to assess the temperament of persons over 13 years of age. The EAS-D questionnaire consists of 20 items constituting 5 scales: Distress (D), Fear (F), Anger (A), Activity (Ac) and Sociability (S). Cronbach's $\alpha$ reliability coefficients are within the limits .57-.74. The questionnaire validity measurement was carried out with the analysis of the intercorrelation matrix between scales, factorial validity, correlation with other temperament and personality traits and genetic testing. Good results were obtained (cf. Oniszczenko, 1997).

The Aggression Questionnaire (Buss \& Perry, 1992) was used to assess individual differences in aggressive personality. The 29-item scale is composed of four subscales: physical aggression, verbal aggression, anger, and hostility. Five-point scale from 1 = extremely uncharacteristic for me to $5=$ extremely characteristic for me. The AQ contains 4 factors: Physical Aggression, Verbal Aggression, Anger, and Hostility. Internal consistency for the four subscales and total score range from .72 (Verbal Aggression) to .89 [Total The Buss-Perry Aggression Questionnaire (BPAQ) score]. Retest reliability for the BPAQ over nine weeks is also satisfactory (correlations ranged from .72 for Anger to .80 for Physical Aggression and for the total score) (Buss \& Perry, 1992).

Information about aggressive behaviour at school was gathered with the Mini Direct and Indirect Ag- gression Inventory (Mini-DIA). The Mini-DIA is an abbreviated version of the Direct-Indirect Aggression Scales (Österman \& Björqvist, 1998), developed as a less time-consuming version of the original instrument. It has been shown to yield similar results as the original scales. Instead of consisting of multiitem scales measuring physical, verbal, and indirect aggression, the scales are instead single-item, and the types of aggression are defined to the respondents as follows: (1) physical aggression: "another pupil has for instance hit, kicked, or pushed you”; (2) verbal aggression: "another pupil has for instance screamed at you, or said hurtful things about you or [added in Iran] your family"; (3) indirect aggression: "another pupil has spread malignant gossip about you, spread untrue stories about you, or tried to freeze you out”. Respondents then state, on a five-point scale, ranging from $0=$ "never" to $4=$ "often", to what extent they have been exposed to these. There is both a Victim and a Perpetrator Version of the Mini-DIA. Cronbach's $\alpha$ reliability coefficients are as follows: Victim scale .90, Perpetrator scale .88 (Österman, 2010). The psychometric validity tests produced satisfactory results, but in Poland we still have their experimental version. The Polish parametrization of this method is still in progress.

In order to evaluate the socio-demographic variables, a questionnaire was used that gathered information about the age and sex of respondents, number of siblings, mother's education, father's education and the family's financial situation.

Characteristics of studied groups: the studied group consisted of 120 members aged between 16 and 19, mainly secondary school students. There were 72 girls $(60 \%)$ and 48 boys ( $40 \%)$ in the studied population. The selection for the studied group was purposive. The selection criterion was biological age ranging between 16 and 19. The criterion was chosen because of the changes taking place over that age period, concerning both psychological functioning and social relations connected with the realization of developmental tasks specific for that age. The study was conducted in groups during school classes under the supervision of a school psychologist in randomly chosen classes of previously randomly chosen post-primary schools of the general education and vocational type. For underage students, parental consent was obtained at parents' conferences during the school year.

The difference between the number of boys and girls represents the actual ratio in the randomly chosen schools.

\section{RESULTS}

In the presented research, particular temperament components were analysed (sociability, activity, anger, fear and distress), as well as attachment com- 
Table 1

Relationships between temperament and aggressiveness level

\begin{tabular}{cccccc}
\hline & $\begin{array}{c}\text { General } \\
\text { aggressiveness level }\end{array}$ & $\begin{array}{c}\text { Hostility } \\
\text { dimension }\end{array}$ & $\begin{array}{c}\text { Anger } \\
\text { dimension }\end{array}$ & $\begin{array}{c}\text { Verbal } \\
\text { reactions }\end{array}$ & $\begin{array}{c}\text { Physical } \\
\text { reactions }\end{array}$ \\
\hline Sociability & .053 & .009 & .170 & .010 & -.077 \\
Activity & -.087 & -.147 & $<.001$ & .044 & -.126 \\
Anger &. $\mathbf{2 7 2 ^ { * * }}$ &. $\mathbf{2 4 8 ^ { * * }}$ &. $\mathbf{2 1 2 ^ { * }}$ &. $\mathbf{1 1 6}$ & $.216^{*}$ \\
Fear & -.024 & .055 & .071 & -.085 & -.160 \\
Distress & .167 &. $\mathbf{2 1 7 ^ { * }}$ & $\mathbf{. 1 9 0 ^ { * }}$ & .121 & -.049 \\
\hline
\end{tabular}

Note. $r$-Pearson, ${ }^{*} p<.50,{ }^{* *} p<.01$

Table 2

Connections between attachment dimensions and aggressiveness

\begin{tabular}{|c|c|c|c|c|c|c|}
\hline $\begin{array}{l}\text { Attachment } \\
\text { dimensions }\end{array}$ & $\begin{aligned} & \text { Trust } \\
- & \text { mother }\end{aligned}$ & $\begin{array}{c}\text { Trust } \\
\text { - father }\end{array}$ & $\begin{array}{c}\text { Communication } \\
- \text { mother }\end{array}$ & $\begin{array}{c}\text { Communication } \\
- \text { father }\end{array}$ & $\begin{array}{l}\text { Alienation } \\
\text { - mother }\end{array}$ & $\begin{array}{c}\text { Alienation } \\
\text { - father }\end{array}$ \\
\hline $\begin{array}{l}\text { Physical and verbal } \\
\text { reactions }\end{array}$ & $.198^{*}$ & -.083 & .105 & .097 & .080 & -.038 \\
\hline Hostility & $.279^{* *}$ & -.176 & .023 & -.030 & .051 & $.224^{*}$ \\
\hline Anger & $.565^{* *}$ & -.114 & .139 & .050 & $.235^{*}$ & $.242^{*}$ \\
\hline $\begin{array}{l}\text { General level } \\
\text { of aggression }\end{array}$ & $.392^{* *}$ & -.175 & .107 & .041 & .180 & .156 \\
\hline
\end{tabular}

Note. ${ }^{*} p<.05,{ }^{* *} p<.01$

ponents (trust, attachment bond, communication and alienation), aggressiveness indicators (general level of aggressiveness, hostility, anger, verbal reactions, physical reactions) and forms of aggressive behaviour (aggressor role, victim role).

The results of statistical analyses indicate the relationships of temperament - in almost all its dimensions - with aggressiveness level. The dimension of temperamental anger is connected both with the general aggression level $(r=.27, p<.001)$, hostility $(r=.25, p<.001)$, aggressiveness-related anger $(r=.21, p<.050)$ and reactions in verbal and physical form $(r=.22, p<.050)$. One should also pay attention to the relationship between temperamental distress and hostility $(r=.25, p<.050)$. The quoted analyses indicate the relationships of particular temperament dimensions with aggressiveness dimensions (cf. Table 1). The regression analysis demonstrated that the type of temperament determines in almost $1 \%$ the hostility dimension $\left(R^{2}=.0134, p<.005\right)$.

The conducted research also reveals a connection between aggressiveness level and dimensions of attachment. The level of trust towards the mother positively correlated with all the aggressiveness aspects, and the level of alienation in the relationship with the father and mother especially correlated with the aggressiveness dimension of anger. Therefore, those two attachment dimensions appear to be important in the origin of aggressive tendencies. A fact worth noting is the well-proven connection between the trust towards mother dimension and all aggressiveness dimensions (cf. Table 2) and the relationship between aggression-related anger and alienation from both mother and father. In the constructed model of regression of determining factors for particular dimensions of aggressiveness, the interdependency between the anger dimension and the level of trust towards the mother was examined. The obtained result indicates that the model explains in $30 \%$ the level of aggression-related anger scored by teenagers $\left(R^{2}=.32\right.$, $F(54,365), p<.001, \beta=.57)$. This may mean that the attachment style factor may influence the feeling of anger that is a component of aggressiveness.

The obtained results confirmed the assumed hypotheses (selected attachment and temperament dimensions are directly linked to aggressiveness) and indicated the correlations of selected attachment aspects (parent trust and alienation) with the aggressiveness level and selected temperament components (temperamental anger and distress) with hostility and anger structures as manifestations of personality-based aggressiveness. Thus, those two dimensions of attachment and temperament seem to be important factors in the genesis of the tendency to aggression. The tested model also verified whether age, sex and socio-demographic features of respondents correlated with their aggressiveness levels. No statistically significant dependencies were found. 
Table 3

Relations between victim/perpetrator type behaviour and other variables

\begin{tabular}{|c|c|c|}
\hline \multirow[b]{2}{*}{ Predictors } & \multicolumn{2}{|c|}{ Aggressive behaviour } \\
\hline & $\begin{array}{l}\text { Victim } \\
\text { role }\end{array}$ & $\begin{array}{c}\text { Perpetrator } \\
\text { role }\end{array}$ \\
\hline Age & $-.227^{*}$ & -.080 \\
\hline $\begin{array}{c}\text { Physical aggression } \\
\text { relations }\end{array}$ & .005 & $.314^{* *}$ \\
\hline $\begin{array}{l}\text { Verbal aggression } \\
\text { relations }\end{array}$ & .087 & $.302^{* *}$ \\
\hline $\begin{array}{l}\text { Aggressiveness- } \\
\text { related anger }\end{array}$ & $.206^{*}$ & .145 \\
\hline $\begin{array}{l}\text { Aggressiveness- } \\
\text { related hostility }\end{array}$ & $.502^{* *}$ & .169 \\
\hline $\begin{array}{c}\text { General level } \\
\text { of aggressiveness }\end{array}$ & $.291^{* *}$ & $.303^{* *}$ \\
\hline
\end{tabular}

Thus, as the conducted research indicates, on the basis of the constructed hierarchical regression model the general level of aggressiveness may be explained in $30 \%$ through temperamental anger and trust in the relationship with the mother $\left(R^{2}=.32, F(54,365)\right.$, $p<.001, \beta$ temp. anger $=.27, \beta$ trust-mother $=.39$ ) . These two factors are in a direct positive correlation with teenagers' aggressiveness level. This means that the higher the level of temperamental anger and mother trust, the higher the aggressiveness. Moreover, these relations are similar with particular aggressiveness components: hostility and verbal/physical reactions.

In the subsequent step, it was verified whether personality-based aggressiveness influences the undertaking of aggressive behaviour, and the relationship of aggressive behaviour with other measured variables was investigated. The research measured such behavioural indicators of aggression as assuming the victim and perpetrator role. The obtained results reveal that taking on the victim role is in a weak positive correlation with the measured level of aggression-related anger $(r=.21, p<.050)$, hostility $(r=.50, p<.001)$ and the general level of aggressiveness $(r=.29, p=.050)$ and in a negative correlation with age $(r=-.23, p<.050)$ (cf. Table 3$)$. The results show that the frequency of assuming the victim role increases with the subjectively experienced level of anger and hostility and at the same time drops with age.

Meanwhile, adopting the aggressor role is positively correlated with such aggressiveness variables as physical aggression reactions $(r=.31, p=.001)$, verbal aggression reactions $(r=.30, p=.001)$ and the general aggressiveness level $(r=.30, p=.010$, Table 3$)$.
This means that the frequency of perpetrator-type behaviour increases with the general aggressiveness level and its verbal and physical manifestations.

The above-presented results indicate that, as assumed in the first hypothesis, the dominant temperament component in persons with a high level of aggressiveness is temperamental anger. Thus, the hypothesis has been confirmed.

The remaining assumptions, also formulated as hypotheses, were either unconfirmed or confirmed only partially. The assumption that insecure attachment (low level of bond and trust, high level of alienation) positively correlates with a high level of aggressiveness has not been confirmed in all its dimensions, and therefore hypothesis no. 2 should be rejected. The detected correlations indicate that a high level of trust and a high level of alienation in the relationship with the mother are connected first of all with one component of aggressiveness, i.e. anger.

As the relationship between sex, age and socio-demographic characteristics of the respondents and the level of their aggressiveness has not been confirmed, hypothesis no. 3 may be refuted in its entirety. On the other hand, the correlations found between aggressiveness level and aggressive behaviour of an individual indicate that the relationship is more complicated than initially assumed. High aggressiveness level is linked, as was expected, to the manifested perpetrator behaviour but, surprisingly, also to victim-type behaviour. Thus, the hypothesis needs to be confirmed, and it needs to be demonstrated that aggressiveness is actually a predictor for aggressive behaviour, both of perpetrator and victim type.

\section{DISCUSSION}

The questions of intra-psychological determinants of aggressiveness level and of the frequency of undertaking aggressor or victim type behaviour tackle many areas connected with the way in which the adolescent mind works in various environments and developmental contexts. The research model was based on the theoretical concept of aggression (the General Aggression Model - GAM) based on the socio-cognitive approach. The GAM indicates the key role played by both individual decisions to take a certain action in a specific situation (e.g. the situation of provocation, threat or attack) and also by an intermediate construct such as readiness for aggression. The choice of that theoretical model was dictated by the fact that it contains all the elements that are vital from the point of view of the research problem: evaluation of the situation, physiological and emotional arousal (temperamental anger) and the emotive-cognitive factor (anger). An individual makes decisions concerning his or her aggressive behaviour on the basis of own past experiences and their consequences 
(Anderson \& Bushman, 2002; Wojciszke, 2011). In the adopted research model, features and properties of an individual may be treated as his or her specific resources that may condition the course of the process of undertaking a certain type of behaviour. As certain factors may vary, the individual's behaviour may differ from one instance to another. Still, the research by Krahé (2014) testifies to the power of cognitive patterns activated by a specific situational stimulus. Due to many references and the possibility of having a very wide discussion involving bio-psychological variables and the undertaken aggressive behaviour in late adolescence when many primary structures may undergo transformation, our discussion shall be limited to the relations between sex and socio-demographic factors, temperament and attachment, and the issues connected with the possibility of looking for connections between personality-based aggressiveness and undertaken aggressive behaviour.

In the present research, the assumptions were verified concerning the role of an individual's subjective traits (such as temperament and attachment) in the shaping of aggressiveness. Also, we carried out an analysis of the relations between aggressiveness and adopting the perpetrator/victim role as an example of the behavioural dimension of aggressiveness. The research refers to the GAM proposed by Anderson and Bushman (2002) and currently widely discussed. Recent studies aimed at verification of that model (Parrot, 2013) accentuate the impact of situational factors on engagement in aggressive behaviour and indicate the indirect and limited impact of personality traits, such as temperament, attachment or aggressiveness, on undertaking and manifesting aggressive behaviour. Still, in the present study the task of estimating the impact of those psychological determinants was undertaken (interdependencies between temperament-related and attachment-related ones and the displayed aggressiveness and between aggressiveness and the actual behaviour of an individual).

The first research outcome that is worth discussing is the absence of any relationship between sex and other socio-demographic data and the demonstrated level of aggressiveness. The results show that a shortening variable, which we understand as biological sex, plays a limited role of in the development of aggressiveness. This is in line with already known research indicating the significance of biological sex in the demonstrated types of aggressiveness. One can mention here the results clearly indicating that men are more often perpetrators of physical aggression than women (Krahé, 2005). However, recent research indicates that aggressive women more often use indirect, relationship-related forms of violence (Björqvist, 1994). Due to the fact that the measurements were taken using a different aggression measurement tool (Frączek, Konopka, \& Smulczyk, 2013), the results cannot be ultimately compared. Still, women dis- played readiness for aggression in the emotional dimension, while men showed a tendency to aggression in the habitual dimension. However, no differences between sexes were revealed on the level of approval for aggressive behaviour. These results point to the influence of the environment and life context that modifies the tendency for aggression manifesting in aggressiveness (cf. Brzezińska, 2005; Lerner, 1982; Obuchowska, 1996). It should also be noted that the present research has limitations in relation to persons with a sufficient level of self-control, as none of the respondents taking part in the research has entered into any conflict with law because of his or her aggressive behaviour. Therefore, it would be interesting to verify the results in a different group of respondents consisting, for instance, of teenagers with diagnosed behavioural problems (cf. Wójcik, 1977).

The second result that should be highlighted is the demonstrated relations of temperament and attachment with the level of aggressiveness. The tool used for the investigation of aggressiveness made it possible to carry out a complete analysis of the impact of temperament and attachment on various manifestations of aggressiveness: its emotional and cognitive component as well as verbal and physical reactions. The study made it possible to observe certain characteristic relationship patterns between particular dimensions of aggressiveness. Univocally moderate relations between the temperamental dimension of anger and all aggressiveness dimensions were obtained. The temperamental anger dimension is connected with the general level of aggressiveness $(r=.27, p<.010)$, hostility $(r=.25, p<.010)$, anger $(r=.21, p<.050)$ and verbal/physical reactions $(r=.22, p<.050)$. The relation between temperamental distress and hostility should also be noted $(r=.25$, $p<.050)$. The quoted analyses indicate the correlations between particular temperament dimensions and aggressiveness dimensions. This has got its theoretical justification; as Rothbart and Bates demonstrated (1998), there are several proofs indicating the relationship between temperament and adjustment. Those relations concerned both positive and negative adjustment, the latter manifesting itself inter alia by aggressive behaviour. As also pointed out in relevant literature, it is highly probable that the processes linking aggression and aggressiveness to temperament are of interactive nature. From that perspective, problems with behaviour may result from mutual relations between temperamental features of a child and adult response to the challenges resulting from those temperamental characteristics (Reid \& Patterson, 1989; Clark, Watson, \& Mineka, 1994; Rothbart, Derryberry, \& Posner, 1994; Rothbart, Posner, \& Hershey, 1995; Rothbart \& Bates, 1998). Nurmi also points out that interactiveness should be taken into consideration in the case of each developing relationship of educational or peer type, as under the influ- 
ence of experiences (particularly adolescent ones) those relationships may acquire a more individual and situation-specific nature (Nurmi, 2004).

The regression analysis revealed that temperament type determines almost $1 \%$ of the hostility dimension $\left(R^{2}=.01, p<.003\right)$. And although the obtained correlations are not particularly strong, they show that temperamental anger is a significant predictor for (global) aggressiveness in its every aspect (emotional - aggression-related anger, cognitive hostility and in the behaviour-related aspect). On the other hand, the dimension of temperamental distress correlates with emotive-cognitive areas. This may mean that this dimension takes part in the recognition of a situation as hostile, provocative or neutral and may be an indicator of one's specific readiness to interpret reality as threatening or hostile. The issue of the impact of hostile attribution style on undertaken aggressive behaviour has been described by Dill, Anderson, Anderson, and Deuser (1997).

The obtained results also point to the correlation between the dimensions of trust and alienation in the attachment dimension and the level of aggressiveness in teenagers. Thus, those two dimensions of attachment seem important for the genesis of aggressive behaviour. The results indicating the presence of moderately positive correlations between trust towards the mother and various dimensions of aggressiveness are particularly interesting and surprising, as the relevant literature rarely mentions that trust in an attachment-type relationship may increase the level of teenage aggressiveness, particularly aggression-related anger. The obtained result shows that the model explains in $32 \%$ the level of aggression-related anger scored by teenagers $\left(R^{2}=.32, F(54,365)\right.$, $p<.001, \beta=.57)$. This means that attachment may have an impact on the feeling of anger, which is a component of aggressiveness. Indirectly, this result may be explained by the incorrect process of development in adolescence as far as shaping one's own identity and independence from one's parents is concerned. The increasing reproductive maturity triggers the evolutionarily adaptive mechanism promoting emotional separation from the family of origin (Steinberg, 1989). Also, the emotional distance between children and their parents widens (Fuligni, 1998; Steinberg, 1988).

In adolescence, young people search for greater independence and more occasions to make their own decisions. This is connected to a considerable degree with the development of abstract thinking, which makes young people display much greater criticism towards their parents with the idealization of the image of parents "as they should be" (Collins, 1990). From the perspective of family psychology, the period of the child's adolescence is a challenge to parents. Due to developmental changes taking place both in the child's cognitive sphere and in the sphere of needs (the rising need for independence and individualisation), parents have to change their style of relationship with their child (Smetana, 2010). Thus, excessive attachment to the mother in that period may be a manifestation of a distorted process of separation and individualization, but that hypothesis requires further empirical verification.

The recognised correlations between the trust towards mother dimension and all the dimensions of aggressiveness, as well as the relations of aggression-related anger with alienation from both mother and father may indicate the genesis of a hostile and rejecting attitude. In the literature that issue was addressed in studies on the impact of parenting styles/ attitudes on readiness for aggression and actually displayed aggressive behaviour. Research results (Bakiera, 2014; Farnicka \& Liberska, 2014; Konopka, Frączek, \& Dominiak-Kochanek, 2013; Rutkowska \& Frączek, 2013) clearly indicate that excessive trust and emotional withdrawal from the relationship may be perceived as neutral or over-permissive, sometimes even as hostile, and connected with the manifested aggression in teenagers and younger children.

The results of investigating the relations between personality-based aggressiveness and undertaken aggressive behaviour (of both perpetrator and victim type) indicate that adopting the victim role is in a weak positive correlation with the measured level of aggression-related anger and the general level of aggressiveness and in a negative correlation with age $(r=-.23, p<.050)$. Thus, the results indicate that the frequency of adopting the victim role increases with the experienced level of aggression-related anger and hostility and decreases with age. Thus, age is a protective factor that minimizes to a certain degree the frequency of being victimised.

It has been noted that adopting the aggressor role is positively correlated with aggressiveness variables, such as physical aggression reactions $(r=.31$, $p=.010)$, verbal aggression reactions $(r=.30, p=.001)$ and the general level of aggressiveness $(r=.30$, $p=001$ ). This means that the frequency of undertaking the perpetrator-type behaviour increases along with the general level of aggressiveness and the frequency of its manifestations in the form of physical and verbal aggression. In this case, one can conclude that there is a self-sustaining spiral of aggressiveness and subsequent acts of aggression (Wójcik, 1977).

The obtained results show the need to differentiate between particular aggressiveness dimensions depending on the undertaken behaviour of the perpetrator or victim type. That differentiation should relate both to determinants of those constructs and their relations with behavioural manifestations. The trait of aggressiveness is influenced by temperament and attachment determinants, but those correlations are limited for actual behaviour. In this regard, the results are in line with the above-discussed GAM model that clearly sep- 
arates the processes related to arousal of an individual and the experienced hostility and anger and triggered information processing from the decision processes in undertaking victim or aggressor behaviour.

\section{SUMMARY}

The described study aimed to determine the significance of attachment relations and temperament for the psychological construct of aggressiveness and for engagement in perpetrator/victim type behaviour. The obtained results point to the direct impact of the closeness deficit and excessive parent trust, as well as temperament dimensions of anger and distress on aggressiveness-related constructs. The conducted research allows one to conclude that temperamental anger is the dominant temperament component in persons characterized by a high level of aggressiveness. Moreover, correlations have been detected indicating that a high level of trust and alienation in the relationship with the mother are linked to anger as an aggressiveness component.

The research also revealed that the correlation between sex, age and socio-demographic characteristics of respondents and their aggressiveness level is insignificant. Still, the protective function of age in victim-type behaviour was demonstrated. Moreover, the revealed relations between aggressiveness level and aggressive behaviour undertaken by an individual indicate that the relationship is significant and more complicated than initially assumed. It was found that a high level of aggressiveness is connected with perpetrator-type behaviour, but also with victim-type behaviour. Undertaking such behaviour depends on the prevailing aggressiveness dimension: the frequency of engaging in perpetrator-type behaviour increases with the general level of aggressiveness and frequency of its manifestation in the physical and verbal form, while the frequency of victim-type behaviour increases with the experienced level of anger and hostility. Thus, a precise evaluation of aggressiveness structures measured with the Buss-Perry questionnaire enables one to predict not only the frequency of aggressive behaviour but also its type (aggressor, victim).

\section{RefERENCES}

Anderson, C. A., \& Bushman, B. J. (2002). Human aggression. Annual Review of Psychology, 53, 27-51.

Anderson, C. A., \& Carnagey, N. L. (2004). Violent evil and the general aggression model. In: A. Miller (ed.), The Social Psychology of Good and Evil (pp. 168-192). New York: Guilford Publications.

Archer, D., \& McDaniel, P. (1995). Violence and gender: Differences and similarities across societies.
In: B. R. Ruback, \& N. A. Wiener (eds.), Interpersonal violent behaviors (pp. 63-87). New York: Springer.

Armsden, G. C., \& Greenberg, M. T. (1987). The inventory of parent and peer attachment: relationships to well-being in adolescence. Journal of Youth and Adolescence, 16, 427-454.

Bakiera, L. (2014). Aversive Parenting. In: C. Pagani, M. Farnicka, H. Liberska, \& J. M. Ramirez (eds.), Social and developmental conditionings (pp. 97-98). Warsaw: Difin.

Barnown, S., Lucht, M., \& Freyberger, H. (2005). Correlates of aggressive and delinquent conduct problems in adolescence. Aggressive Behavior, 31, 24-39.

Berkowitz, L. (2012). A Different view of anger: The cognitive-neoassociation conception of the relation of anger to aggression. Aggressive Behavior, 38, 322-333.

Björqvist, K. (1994). Sex differences in physical, verbal and indirect aggression. Sex Roles, 30, 177-188.

Björqvist, K., Lagerspetz, K. M. J., \& Österman, K. (1992). The Direct and Indirect aggression Scales. Vasa, Finland: Abo Akademi University.

Björqvist, K., Österman, K., \& Lagerspeatz, K. M. J. (1994). Sex differences in covert aggression among adults. Aggressive Behavior, 20, 27-33.

Bowlby, J. (1988). A Secure base. Clinical applications of attachment theory. London: Routledge.

Brzezińska, J. (ed.). (2005). Psychologiczne portrety człowieka. Praktyczna psychologia rozwojowa [Psychological human portraits]. Gdańsk: GWP.

Buss, A. H., \& Perry, M. P. (1992). The aggression questionnaire. Journal of Personality and Social Psychology, 63, 452-459.

Clark, L. A., Watson, D., \& Mineka, S. (1994). Temperament, personality, and the mood and anxiety disorders. Journal of Abnormal Psychology, 103, 103-116.

Cloninger, C. R. (1994). Temperament and personality. Curr Opinion Neurobiol, 4, 266-273.

Cloninger, C. R. (1997). A psychobiological model of personality and psychopathology. Journal of Psychosomatic Medicine, 37, 91-102.

Coie, J., Dodge, K., \& Coppotelli, H. (1982). Dimensions and types of social status: A cross-age perspective. Developmental Psychology, 18, 557-570.

Collins, W. A. (1990). Parentchild relationships in the transition to adolescence: Continuity and change in interaction, affect, and cognition. In: R. Montemayor, G. Adams, T. Gullotta (eds.), Advances in Adolescent Development. Vol. 2. The Transition from Childhood to Adolescence (pp. 85-106). Beverly Hills, CA: Sage Publications.

Dill, K. E., Anderson, C. A., Anderson, K. B., \& Deuser, W. E. (1997). Effects of aggressive personality on social expectations and social perceptions. Journal of Research in Personality, 31, 272-292. 
DeRosier, M. E., Kupersmidth, J. B., \& Patterson, C. J. (1994). Children's academic and behavioral adjustment as a function of the chronicity and proximity of peer rejection. Child Development, 65, 1799-1813.

Dodge, K. A. (1986). A social information processing model of social competence in children. In: M. Perlmutter (ed.), Minnesota Symposium on Child Psychology (Vol. 18). Hillsdale, NJ: Erlbaum.

Dodge, K. A., \& Pettit, G. S. (2003). A biopsychosocial model of the development of chronic conduct problems in adolescence. Developmental Psychology, 39, 349-371.

Eagly, A. H., \& Wood, W. (1999). The origins of aggression sex differences: Evolved dispositions versus social roles. Behavioral and Brain Sciences, 22, 223-224.

Eisenberg, N., Spinrad, T. L., \& Eggum, N. D. (2010). Emotion-related self-regulation and its relation to children's maladjustment. Annual Review of Clinical Psychology, 6, 495-525.

Elliott, D. (1994). Serious violent offenders: onset, developmental course and termination. Criminology, 32, 1-21.

Fagot, B. I., \& Kavanagh, K. (1990). The prediction of antisocial behavior from avoidant attachment classifications. Child Development, 61, 864-873.

Farnicka, M., \& Liberska, H. (2013). Selected conditionings of aggressive behavior among polish student. Psychology Research, 4, 687-692.

Farrington, D. P. (1991). Childhood aggression and adult violence: Early precursors and later-life outcomes. In: D. J. Pepler, \& K. H. Rubin (eds.), The Development and Treatment of Childhood Aggression (pp. 5-29). Hillsdale, NJ: Lawrence Erlbaum.

Fergusson, D. M., Horwood, L. J., \& Ridder, E. M. (2005). Show me the child at seven: The consequences of conduct problems in childhood for psychosocial functioning in adulthood. Journal of Child Psychology and Psychiatry, and Allied Disciplines, 46, 837-849.

Frączek, A., Konopka, K., \& Smulczyk, M. (2013). Sex and country related specificity of readiness for aggression among adolescents. Przegląd Badań Edukacyjnych, 17, 87-97.

Fuligni, A. J. (1998). Parental authority, adolescent autonomy, and parent adolescent relationships: A study of adolescents from Mexican, Chinese, Filipino, and European backgrounds. Developmental Psychology, 34, 782-792.

Gajewski, J., \& Małkowska-Szkutnik, A. (2012). Rodzinne i rówieśnicze czynniki związane z upijaniem się i paleniem tytoniu przez 15-letnią młodzież [Family and peer factors associated with drunkenness and smoking for 15-year-old youth]. Developmental Period Medicine, 4, 322-327.

Garnefski, N., \& Diekstra, R. F. (1996). Perceived social support from family, school, and peers: rela- tionship with emotional and behavioral problems among adolescents. Journal of the American Academy of Child and Adolescent Psychiatry, 35, 16571664.

Grzegorzewska, I. (2013). Odporność psychiczna dzieci alkoholików [Resilience of children of alcoholics]. Warsaw: Wydawnictwo Naukowe Scholar.

Kaźmierczak, M., Błażek, M., \& Pastwa-Wojciechowska, B. (2013). Osobowościowe korelaty postaw przemocy wobec kobiet i mężczyzn z uwzględnieniem poziomu organizacji osobowości O. Krenberga [Personality correlates of attitudes violence against women and men with regard to the level of personality organization O. Krenberg]. Czasopismo Psychologiczne, 19, 37-46.

Kazdin, A. E. (1995). Conduct disorders in childhood and adolescence ( $2^{\text {nd }}$ ed.). Thousand Oaks, CA: Sage.

Konopka, K., Frączek, A., \& Dominiak-Kochanek, M. (2013). Parenting styles and readiness for interpersonal aggression among young adults. Lecture during: XVII Workshop Aggression. Bielefeld, 7-9.11.2013.

Krahé, B. (2005). Agresja [The Social Psychology of Aggression]. Gdańsk: GWP.

Krahé, B. (2014). Sexual aggression in sdolescence: risky sexual scripts and sexual behaviors. Rocznik Lubuski, 75-90.

Kupersmidth, J. B., \& Coie, J. D. (1990). Preadolescent peer status, aggression, and school adjustment as predictors of externalising problems in adolescence. Child Development, 61, 1350-1362.

Lerner, R. M. (1982). Children and adolescents as producers of their development. Developmental Review, 2, 242-320.

Lewis, M., Feiring, C., McGuffog, C., \& Jaskir, J. (1984). Predicting psychopathology in six yearolds from early social relations. Child Development, 55, 123-136.

Lytton, H., \& Romney, D. M. (1991). Parents' differential socialization of boys and girls: A meta-analysis. Psychological Bulletin, 109, 267-296.

Malatesta, C. Z., \& Wilson, A. (1988). Emotion cognition interaction in personality development: A discrete emotions, functionalist analysis. British Journal of Social Psychology, 27, 91-112.

Mazur, J., \& Małkowska-Szkutnik, A. (2011). Wyniki badań HBSC 2010. Raport techniczny [Results of HBSC surveys 2010. Technical Report]. Warsaw: IMiD.

Moffitt, T. E., Caspi, A., Harrington, H., \& Milne, B. J. (2002). Males on the life course persistent and adolescence-limited antisocial pathways: Follow-up at age 26 years. Development and Psychopathology, 14, 179-207.

Morton, B. E., \& Rafto, S. (2006). Sex and Aggression. In: K. Österman, \& K. Björqvist (eds.), Contemporary Research on aggression (pp. 279-287). Abo: Abo Akademi University. 
Nurmi, J.-E. (2004). Socialization and self-development: Channeling, selection, adjustment and reflection. In: R. Lerner, \& L. Steinberg (eds.), Handbook of adolescent psychology (pp. 243-256). New York: Wiley.

Obuchowska, I. (1996). Drogi dorastania [The Ways of Adolescence]. Warszawa: WSiP.

Olewus, D. (1979). Stability of aggressive reaction patterns in males. Psychological Bulletin, 86, 852-875.

Oniszczenko, W. (1997). Kwestionariusz Temperamentu EAS Arnolda H. Bussa i Roberta Plomina. Wersja dla dorostych i dla dzieci. Adaptacja polska. Podręcznik [EAS Arnold H. Buss i Robert Plomin Questionnaire. Polish Adaptation]. Warsaw: PTP.

Österman, K. (2010). The Mini Direct Indirect Aggression Inventory. In: K. Österman (ed.), Indirect and Direct Aggression (pp. 103-111). Frankfurt am Main, Berlin, Bern: Peter Lang.

Österman, K., \& Björkvist, K. (1998). The mini direct indirect aggression inventory. Finland: Abo Akademii.

Paterson, G. R., Reid, J., \& Dishion, T. (1992). Antisocial Boys. Eugene, OR: Castillia.

Parrot, D. (2013). Verification of GAM Model - lecture. XVI Workshop Aggression. Bielefeld, Germany, November 2013.

Reid, J. B., \& Patterson, G. R. (1989). The development of antisocial behaviour patterns in childhood and adolescence. European Journal of Personality, 3, 107-119.

Renken, B., Egeland, B., Marvinney, D., Mangelsdorf, S., \& Sroufe, L. A. (1989). Early childhood antecedents of aggression and passive-withdrwal in early elementary school. Journal of Personality, 57, 257281.

Rothbart, M. K. (2011). Becoming who we are: Temperament and personality in development. New York: Guilford.

Rothbart, M. K., \& Bates, J. E. (1998). Temperament. In: W. Damon (ed.), Handbook of Child Psychology (Vol. 3) (pp. 105-176). New York: John Wiley \& Sons, Inc.

Rothbart, M. K., Derryberry, D., \& Posner, M. I. (1994). A psychobiological approach to the development of temperament. In: J. E. Bates, \& T. D. Wachs (eds.), Temperament: Individual differences at the interface of biology and behaviour (pp. 83116). Washington, DC: American Psychological Association.

Rothbart, M. K., Posner, M. I., \& Hershey, K. L. (1995). Temperament, attention, and developmental psychopathology. In: D. Cicchetti, \& D. J. Cohen (eds.), Manual of developmental psychopathology (Vol. 1) (pp. 315-340). New York: John Wiley \& Sons, Inc.

Rubin, K. H., Bukowski, W. M., \& Parker, J. G. (1998). Peer interactions, relationships, and groups. In: W. Damon (series ed.), \& N. Eisenberg (vol. ed.), Handbook of child psychology: Vol. 3. Social, emo- tional, and personality development $\left(5^{\text {th }}\right.$ ed., pp. 619-700). New York: Wiley.

Rubin, K., Chen, X., McDougall, P., Bowker, A., \& McKinnon, J. (1995). The waterloo longitudinal project: Predicting adolescent internalizing and externalizing problems from early and mid-childhood. Development and Psychopathology, 7, 751764.

Rutkowska, M., \& Frączek A. (2013). Child - rearing practices and readiness for aggression among juvenile delinquents. Lecture during XVII Workshop Aggression. Bielefeld, 7-9.11.2013.

Sanson, A., Oberkleid, F., Pedlow, R., \& Prior, M. (1991). Risk indicators: assessment of infancy predictors of pre-school behavioural maladjustment. Journal of Child Psychology and Psychiatry, 32, 609-626.

Smetana, J. G. (2010). Adolescents, families, and social development: How teens construct their worlds. West Sussex, England: Wiley-Blackwell.

Steinberg, L. (1988). Reciprocal relation between parentchild distance and pubertalmaturation. Developmental Psychology, 24, 122-128.

Steinberg, L. (1989). Pubertal maturation and parentadolescent distance: An evolutionary perspective. In: G. Adams, R. Montemayor, \& T. Gullota (eds.), Advances in Adolescent Development (Vol. 1.) (pp. 71-79). Beverly Hills, CA: Sage Publications.

Wentzel, K. R., \& Asher, S. R. (1995). Academic lives of neglected, rejected, popular, and controversial children. Child Development, 62, 1066-1078.

Wojciszke, B. (2011). Psychologia spoteczna [Social Psychology]. Warsaw: Wydawnictwo Naukowe Scholar.

Wójcik, D. (1977). Środowisko rodzinne a poziom agresywności mtodzieży przestępczej i nieprzestępczej [Family environment and the level of aggressiveness of youth with- and without crime experiences]. Warsaw: PAN.

Zahn-Waxler, C. (1993). Warriors and worriers: Gender and psychopathology. Development and Psychopathology, 5, 79-89.

Zocollilo, M. (1993). Gender and the development of conduct disorder. Development and Psychopathology, 5, 1-2, 65-78. 